\title{
The Effects of Different Concentrations and Combinations of Plant Growth Regulators on Micropropagation Potential of Pomegranates (Punica granatum L.)
}

\author{
Emine Orhan (Corresponding author) \\ Ataturk University, Faculty of Agriculture, \\ Department of Agricultural Biotechnology, 25240 Erzurum, Turkey \\ E-mail: eorhan@atauni.edu.tr \\ Kadir Yuksel \\ Republic of Turkey Ministry of Agriculture and Forestry, Directorate of Provincial Agriculture and \\ Forestry, Agri, Turkey \\ E-mail: kadiryuksel.kyk72@gmail.com \\ Murat Aydin \\ Ataturk University, Faculty of Agriculture, \\ Department of Agricultural Biotechnology, 25240 Erzurum, Turkey \\ E-mail: maydin@atauni.edu.tr
}

\begin{abstract}
A pomegranate fruit with rich nutrient content has a great importance in terms of human health. As a result, the increase in pomegranate consumption necessitated the establishment of new gardens. For this reason, to obtain new clonal pomegranate plants in a short time, in vitro micropropagation based on tissue culture techniques is gaining importance. The aim of this study was to investigate the effects of plant growth regulators at different concentrations and combinations on the micropropagation potential of pomegranates. In this study, the different combinations of BAP (1.5-2.0-2.5 mg L $\left.{ }^{-1}\right)$, NAA (0.5-1.0-1.5 $\left.\mathrm{mg} \mathrm{L}^{-1}\right)$ and AC (activated charcoal) $(0-0.02 \%)$ concentrations were applied in both full-solid and semisolid MS basal medium. According to the general evaluation in terms of the content of the culture medium, the best results were obtained from Medium-4 (MS+4 mg L ${ }^{-1}$ Agar $+0 \% \mathrm{AC}$ ) and Medium-3 (MS+8 $\mathrm{mg} \mathrm{L}^{-1}$ Agar $\left.+0 \% \mathrm{AC}\right)$ that the activated charcoal was not used. In medium-4 prepared as activated charcoal-free and semi-solid, the average callus rate, the average callus size and the average number of shoots were recorded as $86.00 \%, 87.40 \mathrm{~mm}^{2}$ and 10.30 , respectively. In medium-3 prepared as activated charcoal-free and full-solid, the average callus rate, the average callus size and the average number of shoots were recorded as $83.67 \%, 86.37 \mathrm{~mm}^{2}$ and 18.43 , respectively. In our study, shoot regeneration occurred through indirect organogenesis. The highest shoot regeneration of pomegranate cotyledons was obtained from Medium-3 (MS+8 mg L $\mathrm{m}^{-1}$ Agar $+0 \% \mathrm{AC}$ ) containing $2.0 \mathrm{mg} \mathrm{L} \mathrm{BAP}^{-1} \mathrm{Bnd}$ $1.0 \mathrm{mg} \mathrm{L}{ }^{-1} \mathrm{NAA}$ with 43.3 shoots per explant. Results of this study, the clonal micropropagation of pomegranate genotypes and varieties determined as a result of plant breeding studies will be contributed.
\end{abstract}

Keywords: Pomegranate, Plant growth regulators, Callus regeneration

DOI: $10.7176 / \mathrm{JSTR} / 5-12-16$

\section{Introduction}

The pomegranate fruit species is found in the genus Punica and is widely distributed in the areas from Mediterranean region to Asia, North Africa, Europe and this species is one of the oldest fruit species (B.C. 3000-4000) with cultivated edible fruits (Chandra et al. 2010). Transcaucasian-Caspian region and the northern parts of Turkey are mentioned as the place where the pomegranate plant begins to culture (Zohary and Spiegel-Roy 1975; Harlan 1992). Today, pomegranate is grown in subtropical and tropical areas of the world in different climatic conditions. The Mediterranean countries are the major countries 
where commercial cultivation of pomegranate plants is being carried out (Silva et al. 2013). In Turkey, the pomegranate production amount was recorded as about 500.000 tons and the number of pomegranate trees in the age of fruit was recorded as 13.6 thousand pieces according to TUIK (Turkish Statistical Institute) (Anonymous 2018). With the understanding of the value of pomegranate fruits in terms of health, the demand of people for this fruit has increased and the economic value of the fruit has also increased. So far, many studies have been carried out around the world in the field of micropropagation of pomegranate plants and these studies have resulted in different success rates. For example; nutrient medium composition, different concentrations and combinations of plant growth regulators, environmental conditions (temperature, light intensity, etc.), genotype and physiological status of the plant were found to be important in micropropagation. In addition, the success of in vitro propagation depends on the selection of a suitable plant part to serve as starting material. Until now, cotyledon and shoot parts of the seedlings obtained after seed germination in vitro and the shoot tips obtained from mature pomegranate plants have been used as explant resources in micropropagation studies. As a result of the studies, it is known that the use of node parts is generally better than the shoot tips (Naik and Chand 2011). Nutrient composition also plays an important role in plant tissue culture studies. The most common medium used as the primary nutrient medium in micropropagation of pomegranate plants were the MS (Murashige and Skoog) nutrient medium. It is stated that some pomegranate varieties have good results with semi-strong MS medium (1/2 MS), 1/2 WPM medium (Lloyd and McCown 1980) and 1/2 B5 medium (Gamborg et al. 1968) (Naik and Chand 2011). BAP (6-Benzylaminopurine) is a plant growth regulator that stimulates shoots in plant tissue culture studies and is used alone or in combination with other plant growth regulators (Naik and Chand 2011).

Several studies have been carried out on the pomegranate in vitro culture and various protocols have been developed for plant regeneration by organogenesis and somatic embryogenesis. Tissue culture is the only viable technique for clonal propagation of large numbers of standard healthy plants in a short time. Although the pomegranate plants can be vegetative propagated with woody and semi-woody cuttings, these rooted cuttings require about one year for transfer to the field. In addition, the vegetative propagation coefficient in propagation with cuttings is low. Although the pomegranate plants can be propagated by the seed, the heterozygosity is high and a sample material (clonal) is not possible. Because of these reasons, in vitro micropropagation by tissue culture becomes important for fast clonal propagation in pomegranate plants. In addition, fast and efficient regeneration protocols need to be developed. It has been reported that multiple shoots can be propagated from apical and axillary buds (Sriskandarajah, 1994; Naik and Chand, 2003).

The aim of this study was to investigate the effects of plant growth regulators at different concentrations and combinations on the micropropagation potential of pomegranates.

\section{Materials and methods}

\subsection{Plant Materials}

The fruits of the 'Hicaz' pomegranate variety preferred in this study were obtained from a cultural orchard in Mersin city located in the Mediterranean region of Turkey. Seeds of pomegranate fruits were collected from fully matured fruits and washed free of the juicy testa. The seeds were planted in plastic seedling pots containing peat (Figure 3.1a and Figure 3.1b). The germination in pomegranate seeds was obtained in 15 days, in the plant growth cabinet $\left(25^{\circ} \mathrm{C}\right.$ temperature, 16:8 hours' photoperiod, 2500-3000 lux light intensity). The pomegranate cotyledons obtained by seed germination were used as explant source.

\subsection{Culture medium content}

In this study, a total of thirty six experimental combinations were studied. The MS basal medium developed by Murashige and Skoog (1962) was used as an in vitro culture medium. The MS medium was prepared in two forms, full-solid and semi-solid $\left(8.0 \mathrm{~g} \mathrm{~L}^{-1}\right.$ and $4.0 \mathrm{~g} \mathrm{~L}^{-1}$ agar). In this study, plant growth regulators were tested in different concentrations and combinations for shoot regeneration at pomegranate cotyledon explants. BAP (6-Benzylaminopurine) was used at concentrations of 1.5-2.0-2.5 $\mathrm{mg} \mathrm{L}^{-1}$ and NAA (1-Naphthaleneacetic acid) was used at concentrations of $0.5-1.0-1.5 \mathrm{mg} \mathrm{L}^{-1}$. In addition, the activated charcoal (AC) has also been tested in culture medium in order to protect the explants against tissue breakdowns as phenolic compounds can be secreted by cutting in pomegranate explants. For this, activated charcoal $(0,02 \%)$ and activated charcoal-free culture medium were tested in the study (Table 2.1).

The $\mathrm{pH}$ value of the culture medium was set at 5.8 and the sucrose was used to $20.0 \mathrm{~g} \mathrm{~L}^{-1}$. An autoclaving process was carried out at $120^{\circ} \mathrm{C}$ for 15 minutes. The vitamins and plant growth regulators were added using a $0.2 \mu \mathrm{m}$ porous nitrate cellulose filter in the autoclaved and cooled culture medium. 
Table 2.1. The applications tested in both full-solid MS and semi-solid MS basal medium for the micropropagation of pomegranates (BAP: 6-Benzylaminopurine, NAA: 1-Naphthaleneacetic acid, AC: Activated charcoal)

\begin{tabular}{|c|c|c|}
\hline NAA $\left(\mathrm{mg} \mathrm{L}^{-1}\right)$ & $\mathbf{B A P}\left(\mathrm{mg} \mathrm{L}^{-1}\right)$ & \\
\hline $0.5-1.0-1.5$ & 1.5 & \\
\hline $0.5-1.0-1.5$ & 2.0 & \\
\hline $0.5-1.0-1.5$ & 2.5 & \\
\hline NAA $\left(\mathrm{mg} \mathrm{L}^{-1}\right)$ & $\mathbf{B A P}\left(\mathrm{mg} \mathrm{L}^{-1}\right)$ & AC (\%) \\
\hline $0.5-1.0-1.5$ & 1.5 & \multirow{3}{*}{0.02} \\
\hline $0.5-1.0-1.5$ & 2.0 & \\
\hline $0.5-1.0-1.5$ & 2.5 & \\
\hline
\end{tabular}

\subsection{Explant surface sterilization and initiation of culture}

The pomegranate cotyledons washed for about 5-10 minutes under tap water were held for about 45-50 seconds in $70 \%$ ethyl alcohol. Then, surface sterilization was performed for 15 minutes in a $10 \%$ sodium hypochlorite solution with 2-3 drops of Tween-20. Then, cotyledons were washed three times with sterile distilled water in a sterile laminar cabinet. The pomegranate cotyledon explants were placed in small pieces on nutrient medium prepared at different plant growth regulator concentrations and combinations. Each cotyledon was cut into 10 equal parts under sterile conditions (first with a longitudinal cut and then with 4 vertical cuts). On the other hand, petri dishes were prepared for applications. 30 milliliters of culture medium were dispensed into 120 milliliters petri dishes. The petri dishes containing the explants were placed in the plant growing cabinet $\left(25^{\circ} \mathrm{C}\right.$ temperature and 16:8 hours' photoperiod) and culture was started.

\subsection{Statistical analysis}

All the experiments were replicated three times. One-way ANOVA (IBM SPSS-20) was performed to determine the significance of treatment and also to determine the interaction between factors.

\section{Results}

The aim of this study was to determine the micropropagation potential of pomegranate genotypes and cultivars. The different combinations of BAP (1.5-2.0-2.5 mg L $\left.\mathrm{m}^{-1}\right)$, NAA $\left(0.5-1.0-1.5 \mathrm{mg} \mathrm{L}^{-1}\right)$ and AC (0-0.02\%) concentrations were applied in both full-solid and semi-solid MS basal medium. As a result of these applications using pomegranate cotyledon explants, the callus rate of explants (\%), the callus size $\left(\mathrm{mm}^{2}\right)$ of explants and total number of shoots have been determined in significant differences. The statistical analysis showed that there were significant differences among tested applications $(p<0.05)$. The results of these applications and statistical analyzes are summarized in Table 3.1.

According to the general evaluation in terms of the content of the culture medium, the best results were obtained from Medium-4 (MS+4 mg L ${ }^{-1}$ Agar $+0 \%$ AC) and Medium-3 (MS+8 $\mathrm{mg} \mathrm{L}^{-1} \mathrm{Agar}+0 \% \mathrm{AC}$ ) that the activated charcoal was not used. In medium- 4 prepared as activated charcoal-free and semi-solid, the average callus rate, the average callus size and the average number of shoots were recorded as $86.00 \%, 87.40 \mathrm{~mm}^{2}$ and 10.30 , respectively. In medium-3 prepared as activated charcoal-free and fullsolid, the average callus rate, the average callus size and the average number of shoots were recorded as $83.67 \%, 86.37 \mathrm{~mm}^{2}$ and 18.43 , respectively. The expected results were not obtained in both solid and semi-solid nutrient mediums (Medium-1: MS $+8 \mathrm{mg} \mathrm{L}^{-1} \mathrm{Agar}+0.02 \% \mathrm{AC}$ and Medium-2: MS+4 mg L ${ }^{-1}$ Agar $+0.02 \% \mathrm{AC}$ ) containing activated charcoal. That is, there was no shoot regeneration from callus obtained from pomegranate cotyledon explants.

The highest callus formation rate in Medium-1 (MS+8 mg L-1 Agar $+0.02 \% \mathrm{AC})$ was found in application of $2.0 \mathrm{mg} \mathrm{L}^{-1} \mathrm{BAP}+1.5 \mathrm{mg} \mathrm{L}^{-1} \mathrm{NAA}(46.67 \%)$. This value was followed by $1.5 \mathrm{mg} \mathrm{L}^{-1} \mathrm{BAP}$ $+1.5 \mathrm{mg} \mathrm{L}^{-1} \mathrm{NAA}(43.33 \%) ; 2.0 \mathrm{mg} \mathrm{L}^{-1} \mathrm{BAP}+0.5 \mathrm{mg} \mathrm{L}^{-1} \mathrm{NAA}(26.67 \%)$ and $1.5 \mathrm{mg} \mathrm{L}^{-1} \mathrm{BAP}+0.5$ mg $L^{-1}$ NAA (13.33\%), respectively. No callus formation was observed in other applications. In the Medium-2 (MS+4 mg L ${ }^{-1}$ Agar $+0.02 \% \mathrm{AC}$ ), the highest callus formation rate was observed in the combinations of $2.0 \mathrm{mg} \mathrm{L}^{-1} \mathrm{BAP}+1.0 \mathrm{mg} \mathrm{L}^{-1} \mathrm{NAA}(\% 76.67)$ and $2.5 \mathrm{mg} \mathrm{L}^{-1} \mathrm{BAP}+1.0 \mathrm{mg} \mathrm{L}^{-1} \mathrm{NAA}$ (\%76.67). These values were followed by $2.0 \mathrm{mg} \mathrm{L}^{-1} \mathrm{BAP}+1.5 \mathrm{mg} \mathrm{L}^{-1} \mathrm{NAA}(33.33 \%)$ and $1.5 \mathrm{mg} \mathrm{L}^{-1}$ $\mathrm{BAP}+0.5 \mathrm{mg} \mathrm{L}^{-1} \mathrm{NAA}(10.0 \%)$, respectively. No improvement was observed in the other combinations. While the maximum callus formation rate have occurred in applications of $1.5 \mathrm{mg} \mathrm{L}^{-1} \mathrm{BAP}+0.5 \mathrm{mg} \mathrm{L}^{-1}$ 
NAA (96.67\%); $1.5 \mathrm{mg} \mathrm{L}^{-1} \mathrm{BAP}+1.0 \mathrm{mg} \mathrm{L}^{-1} \mathrm{NAA}(96.67 \%) ; 1.5 \mathrm{mg} \mathrm{L}^{-1} \mathrm{BAP}+1.5 \mathrm{mg} \mathrm{L}^{-1} \mathrm{NAA}$ (96.67\%); $2.0 \mathrm{mg} \mathrm{L}^{-1} \mathrm{BAP}+0.5 \mathrm{mg} \mathrm{L}{ }^{-1} \mathrm{NAA}$ (96.67\%) in Medium-3 (MS+8 mg L $\mathrm{mgar}^{-1}$ Ag\% AC ), the minimum callus formation rate was observed in application of $2.5 \mathrm{mg} \mathrm{L}^{-1} \mathrm{BAP}+1.0 \mathrm{mg} \mathrm{L} \mathrm{NAA}^{-1} \mathrm{NA}$ (23.33\%). In Medium-3, the maximum number of shoots was recorded as $43.33\left(2.0 \mathrm{mg} \mathrm{L}^{-1} \mathrm{BAP}+1.0\right.$ mg L $\left.{ }^{-1} \mathrm{NAA}\right)$. In Medium-4 (MS+4 mg L ${ }^{-1}$ Agar $\left.+0 \% \mathrm{AC}\right)$, the best results were found in the combinations of $1.5 \mathrm{mg} \mathrm{L}^{-1} \mathrm{BAP}+0.5 \mathrm{mg} \mathrm{L}^{-1} \mathrm{NAA}(100 \%) ; 1.5 \mathrm{mg} \mathrm{L}^{-1} \mathrm{BAP}+1.5 \mathrm{mg} \mathrm{L}^{-1} \mathrm{NAA}(100 \%)$ and $2.0 \mathrm{mg} \mathrm{L}^{-1} \mathrm{BAP}+1.0 \mathrm{mg} \mathrm{L}{ }^{-1} \mathrm{NAA}(100 \%)$. In Medium-4, the maximum number of shoots was recorded as 32.33 from the application of $1.5 \mathrm{mg} \mathrm{L}^{-1} \mathrm{BAP}+1,5 \mathrm{mg} \mathrm{L}^{-1} \mathrm{NAA}$.

Table 3.1. The statistical evaluation of plant growth regulators in different concentrations and combinations in full solid and semi-solid Murashige-Skoog basal medium (BAP: 6-benzylaminopurine, NAA: 1-naphthaleneacetic acid, AC: Activated charcoal)

\begin{tabular}{|c|c|c|c|c|}
\hline Nutrient Medium Content & $\begin{array}{l}\text { Plant growth regulator combinations } \\
\left(\text { BAP+NAA) }\left(\mathrm{mg} \mathrm{L}^{-1}\right)\right.\end{array}$ & $\begin{array}{c}\text { Callus rate } \\
(\%)\end{array}$ & $\begin{array}{l}\text { Callus size } \\
\left(\mathrm{mm}^{2}\right)\end{array}$ & $\begin{array}{l}\text { Total number } \\
\text { of shoots }\end{array}$ \\
\hline \multirow{11}{*}{$\begin{array}{c}\text { Medium-1 } \\
\left(\mathrm{MS}+8 \mathrm{mg} \mathrm{L}^{-1} \mathrm{Agar}+0.02 \% \mathrm{AC}\right)\end{array}$} & $1.5+0.5$ & 13.33 & 12.20 & 0.00 \\
\hline & $1.5+1.0$ & 0.00 & 0.00 & 0.00 \\
\hline & $1.5+1.5$ & 43.33 & 52.33 & 0.00 \\
\hline & $2.0+0.5$ & 26.67 & 23.00 & 0.00 \\
\hline & $2.0+1.0$ & 10.00 & 11.67 & 0.00 \\
\hline & $2.0+1.5$ & 46.67 & 45.33 & 0.00 \\
\hline & $2.5+0.5$ & 0.00 & 0.00 & 0.00 \\
\hline & $2.5+1.0$ & 0.00 & 0.00 & 0.00 \\
\hline & $2.5+1.5$ & 0.00 & 0.00 & 0.00 \\
\hline & $0.0+0.0$ & 13.33 & 6.67 & 0.00 \\
\hline & Average & 15.33 & 15.12 & 0.00 \\
\hline \multirow{11}{*}{$\begin{array}{c}\text { Medium-2 } \\
\left(\mathrm{MS}+4 \mathrm{mg} \mathrm{L}^{-1} \mathrm{Agar}+0.02 \% \mathrm{AC}\right)\end{array}$} & $1.5+0.5$ & 10.00 & 10.67 & 0.00 \\
\hline & $1.5+1.0$ & 0.00 & 0.00 & 0.00 \\
\hline & $1.5+1.5$ & 0.00 & 0.00 & 0.00 \\
\hline & $2.0+0.5$ & 0.00 & 0.00 & 0.00 \\
\hline & $2.0+1.0$ & 76.67 & 70.33 & 0.00 \\
\hline & $2.0+1.5$ & 33.33 & 28.00 & 0.00 \\
\hline & $2.5+0.5$ & 6.67 & 11.67 & 0.00 \\
\hline & $2.5+1.0$ & 76.67 & 42.33 & 0.00 \\
\hline & $2.5+1.5$ & 0.00 & 0.00 & 0.00 \\
\hline & $0.0+0.0$ & 0.00 & 0.00 & 0.00 \\
\hline & Average & 20.33 & 16.30 & 0.00 \\
\hline \multirow{11}{*}{$\begin{array}{c}\text { Medium-3 } \\
\left(\mathrm{MS}+8 \mathrm{mg} \mathrm{L}^{-1} \mathrm{Agar}+0 \% \mathrm{AC}\right)\end{array}$} & $1.5+0.5$ & 96.67 & 136.00 & 10.33 \\
\hline & $1.5+1.0$ & 96.67 & 108.67 & 17.67 \\
\hline & $1.5+1.5$ & 96.67 & 99.33 & 30.00 \\
\hline & $2.0+0.5$ & 96.67 & 127.33 & 36.33 \\
\hline & $2.0+1.0$ & 86.67 & 85.00 & 43.33 \\
\hline & $2.0+1.5$ & 70.00 & 74.00 & 33.33 \\
\hline & $2.5+0.5$ & 83.33 & 82.00 & 0.00 \\
\hline & $2.5+1.0$ & 23.33 & 14.67 & 0.00 \\
\hline & $2.5+1.5$ & 93.33 & 92.00 & 13.33 \\
\hline & $0.0+0.0$ & 93.33 & 44.67 & 0.00 \\
\hline & Average & 83.67 & 86.37 & 18.43 \\
\hline \multirow{11}{*}{$\begin{array}{c}\text { Medium-4 } \\
\left(\mathrm{MS}+4 \mathrm{mg} \mathrm{L}^{-1} \text { Agar + 0\% AC) }\right.\end{array}$} & $1.5+0.5$ & 100,00 & 99.00 & 11.67 \\
\hline & $1.5+1.0$ & 0.00 & 22.00 & 0.00 \\
\hline & $1.5+1.5$ & 100.00 & 98.67 & 32.33 \\
\hline & $2.0+0.5$ & 96.67 & 128.67 & 15.67 \\
\hline & $2.0+1.0$ & 100.00 & 109.67 & 20.00 \\
\hline & $2.0+1.5$ & 93.33 & 83.00 & 3.67 \\
\hline & $2.5+0.5$ & 83.33 & 98.00 & 3.67 \\
\hline & $2.5+1.0$ & 96.67 & 92.67 & 16.00 \\
\hline & $2.5+1.5$ & 90.00 & 79.33 & 0.00 \\
\hline & $0.0+0.0$ & 100.00 & 63.00 & 0.00 \\
\hline & Average & 86.00 & 87.40 & 10.30 \\
\hline \multirow{11}{*}{ Average } & $1.5+0.5$ & 55.00 & 64.47 & 5.50 \\
\hline & $1.5+1.0$ & 24.17 & 32.67 & 4.42 \\
\hline & $1.5+1.5$ & 60.00 & 62.58 & 15.58 \\
\hline & $2.0+0.5$ & 55.00 & 69.75 & 13.00 \\
\hline & $2.0+1.0$ & 68.33 & 69.17 & 15.83 \\
\hline & $2.0+1.5$ & 60.83 & 57.58 & 9.25 \\
\hline & $2.5+0.5$ & 43.33 & 47.92 & 0.92 \\
\hline & $2.5+1.0$ & 49.17 & 37.42 & 4.00 \\
\hline & $2.5+1.5$ & 45.83 & 42.83 & 3.33 \\
\hline & $0.0+0.0$ & 51.67 & 28.58 & 0.00 \\
\hline & Average & 51.33 & 51.30 & 7.18 \\
\hline \multicolumn{2}{|c|}{ F value (PlantGrowthRegulator) (PGR) } & $25.29^{* *}$ & $156.55^{* *}$ & $1237.39^{* *}$ \\
\hline \multicolumn{2}{|c|}{ F value (Medium Content) (MC) } & $717.72^{* *}$ & $2750.27^{* *}$ & $726.82^{* *}$ \\
\hline \multicolumn{2}{|c|}{ F value (PGR x MC) } & $31.02^{* * *}$ & $115.48^{* *}$ & $739.66^{* *}$ \\
\hline \multicolumn{2}{|c|}{ LSD value $_{(0.05)}(\mathrm{PGR})$} & 6.29 & 3.50 & 0.47 \\
\hline \multicolumn{2}{|c|}{ LSD value $e_{(0.05)}(\mathrm{MC})$} & 3.98 & 2.21 & 0.30 \\
\hline \multirow{2}{*}{\multicolumn{2}{|c|}{$\begin{array}{l}\text { LSD value }_{(0.05)}(\text { PGR x MC) } \\
\text { Variationcoefficient ( } \%)\end{array}$}} & 12.59 & 7.00 & 0.94 \\
\hline & & 14.50 & 8.36 & 8.03 \\
\hline
\end{tabular}


As a result of our study, considering the nutrient medium content, the highest callus rate was obtained as $86.00 \%$ ( $4 \mathrm{~g} \mathrm{~L}^{-1}$ Agar $+0 \%$ active charcoal). This value was followed by medium containing $8 \mathrm{~g} \mathrm{~L}^{-1}$ Agar $+0 \%$ activated charcoal with a ratio of $83.67 \%$. The callus ratio in the semi-solid and full-solid mediums using $0.02 \%$ activated charcoal was $20.33 \%$ and $15.33 \%$, respectively. When the main effect of plant growth regulators on the callus formation rate is examined, the maximum average callus rate was obtained at $2 \mathrm{mg} \mathrm{L}^{-1} \mathrm{BAP}+1 \mathrm{mg} \mathrm{L}^{-1} \mathrm{NAA}(68.33 \%)$. This application was followed by $2 \mathrm{mg} \mathrm{L}^{-1}$ $\mathrm{BAP}+1.5 \mathrm{mg} \mathrm{L}^{-1} \mathrm{NAA}(60.83 \%), 1.5 \mathrm{mg} \mathrm{L}^{-1} \mathrm{BAP}+1.5 \mathrm{mg} \mathrm{L}^{-1} \mathrm{NAA}(60 \%), 1.5 \mathrm{mg} \mathrm{L}^{-1} \mathrm{BAP}+0.5 \mathrm{mg}$ $\mathrm{L}^{-1}$ NAA $(55.00 \%)$ applications, respectively.

\section{Discussions}

In some fruit species, during the tissue culture, some phenolic compounds synthesized in the plant can be secreted into culture medium with cutting of explants. For this reason, tissue culture studies may result in explant conflicts, explant deaths and medium conflicts. In this study, activated charcoal was also added to the nutrient medium and the effect of possible explant declines and explant mortality was tried. However, it is observed that; no blackening of cells has been observed in pomegranate ('Hicaz' variety) cotyledon explants used in our study. On the contrary, it has been found that applications with activated charcoal have a more unsuccessful result than those without activated charcoal. Likewise, the expected results are not obtained from the semi-solid MS medium, which is expected to be more absorbent to phenolic and toxic compounds such as the AC medium. It has been found that the successful results for callus formation in pomegranate cotyledon explants were obtained with increasing BAP (cytokinin group hormone) and NAA (auxin group hormone) concentrations. On the other hand, it has been found that the combined use of cytokinin group hormones and auxine group hormones were more successful in increasing in vitro regeneration than the use of the culture medium containing only cytokinin or only auxin.

In our study, shoot regeneration occurred through indirect organogenesis. The highest shoot regeneration of pomegranate cotyledons was obtained from Medium-3 (MS+8 mg L ${ }^{-1}$ Agar $+0 \%$ AC) containing 2.0 $\mathrm{mg} \mathrm{L}^{-1} \mathrm{BAP}$ and $1.0 \mathrm{mg} \mathrm{L}^{-1} \mathrm{NAA}$ with 43.3 shoots per explant (Figure 3.1d and Figure 3.1e). Similarly, as stated in some literature studies, shoot regeneration from different explant sources has been successful in cytokine-rich media. For example, in a study using cotyledon explants of the 'Ganesh' pomegranate seedlings, callus induction was achieved from MS nutrient medium containing $1 \mathrm{mg} \mathrm{L}^{-1} \mathrm{BA}$ and $0.5 \mathrm{mg}$ $\mathrm{L}^{-1}$ NAA (Murkute et al. 2002). In a research by Patil et al. (2011), when the amount of cytokine was used twice as much as the amount of auxin, a successful result was obtained. In a direct organogenesis study (Parmar et al. 2013), hypocotyl explants of pomegranate cultivar named 'Kandhari Kabuli' were used. The highest shoot regeneration rate (68.21\%)was obtained from MS medium containing $2.0 \mathrm{mg}$ $\mathrm{L}^{-1} \mathrm{BAP}$ and $1.5 \mathrm{mg} \mathrm{L}^{-1} \mathrm{NAA}$ (a number of shoots of 3.18 per explant). In a study carried out by Amin et al. (1999), the best results were obtained from $1 / 2 \mathrm{MS}+1.0 \mathrm{mg} \mathrm{L}^{-1} \mathrm{BAP}+0.1 \mathrm{mg} \mathrm{L}^{-1} \mathrm{NAA}$ application. In a study tested by Kantharajah et al. (1998), the best callus formation was obtained from MS nutrient medium containing $1 \mathrm{mg} / \mathrm{L}$ BAP from axenic leaf explants of 'Wonderful' pomegranate variety. Naik and Chand (2003), have achieved successful results through direct organogenesis. $(8.9 \mu \mathrm{mol} \mathrm{L}-1$ BA and5.4 $\left.\mu \mathrm{mol} \mathrm{L}{ }^{-1} \mathrm{NAA}\right)$.In another research that both benzyl adenine (BA) and kinetin $(\mathrm{Kn})(2.3-23.0 \mu \mathrm{M})$ were tested for shoot regeneration at the pomegranate cotyledon knots, the maximum number of shoots $(9.8$ shoots per explant) were obtained from medium containing 9.0 $\mu \mathrm{M}$ BA (Naik and Chand 2011). On the other hand, in some studies that the cotyledon explants were used, the successful results were obtained in media where the amount of cytokine and the amount of auxin were used equally. For examples; 'Ganesh' pomegranate cotyledons (Foughat et al. 1997) and 'Kandhari anar' pomegranate cotyledons (Jaidka and Mehra 1986). Deepika and Kanwar (2010) preferred to use cotyledon, hypocotyl, internode and leaf explants (Punica granatum L. cv. 'Kandhari Kabuli'). As a result of this study, the highest percentage of callus was obtained from cotyledon explants $(85.50 \%)$ followed by hypocotyl (79.67\%), internode $(79.47 \%)$ and leaf $(75.48 \%)$ explants. In addition to, the maximum number of shoots were obtained at $\mathrm{MS}+9 \mu \mathrm{M}$ BAP $+2.5 \mu \mathrm{M}$ NAA application. Cotyledon derived callus showed the highest regeneration rate $(81.97 \%$, with mean number of 16.47 shoots per explant) followed by hypocotyl, internode and leaf derived calli. Kalalbandi et al. (2014) were tested different explant species in micropropagation study using the 'Bhagwa' pomegranate variety. As a result of this study, the maximum number of shoots ( 1.73 shoots per explant) was obtained from MS medium containing $2.0 \mathrm{mg} \mathrm{L}^{-1}$ BAP. In a study by Kanwar et al. (2010), the highest shoot induction has obtained at MS medium containing 8 $\mu \mathrm{M}$ BA $+6 \mu \mathrm{M}$ NAA $+6 \mu \mathrm{M}$ GA. Omura et al. (1987a) have preferred the mature leaves of the kind of stunted pomegranate named 'Issaizakuro' as explant source. The researchers have obtained callus formation from the mediums of $\mathrm{MS}+5 \mu \mathrm{M} \mathrm{BAP}+0.5 \mu \mathrm{M}$ NAA and $\mathrm{MS}+1.0 \mu \mathrm{M} \mathrm{BAP}+0.5 \mu \mathrm{M}$ NAA 
(cytokinin-rich medium). Omura et al. (1987b), the best callus formation rate has obtained from the medium of $\mathrm{MS}+10 \mu \mathrm{M}$ BAP $+1 \mu \mathrm{M}$ NAA in dwarf pomegranate (Punica granatum L. var. Nana). In another study investigated by Temiz (2009), two pomegranate varieties (Hicaz and Silifke Aşısı) have used. In the study of this researcher, different explant types (leave, hypocotyl, cotyledon, root explant) and different growth regulator combinations (2,4-D and BA) on somatic embryogenesis were investigated. The results have indicated that callus formation in Silifke Aşısı variety (36.60\%) gave better results than Hicaz variety $(32.58 \%)$. Putative embryogenic calluses were obtained from the explants; cotyledon (10.1\%), hypocotyl $(9.78 \%)$, root $(8.53 \%)$ and leave $(7.53 \%)$ respectively.
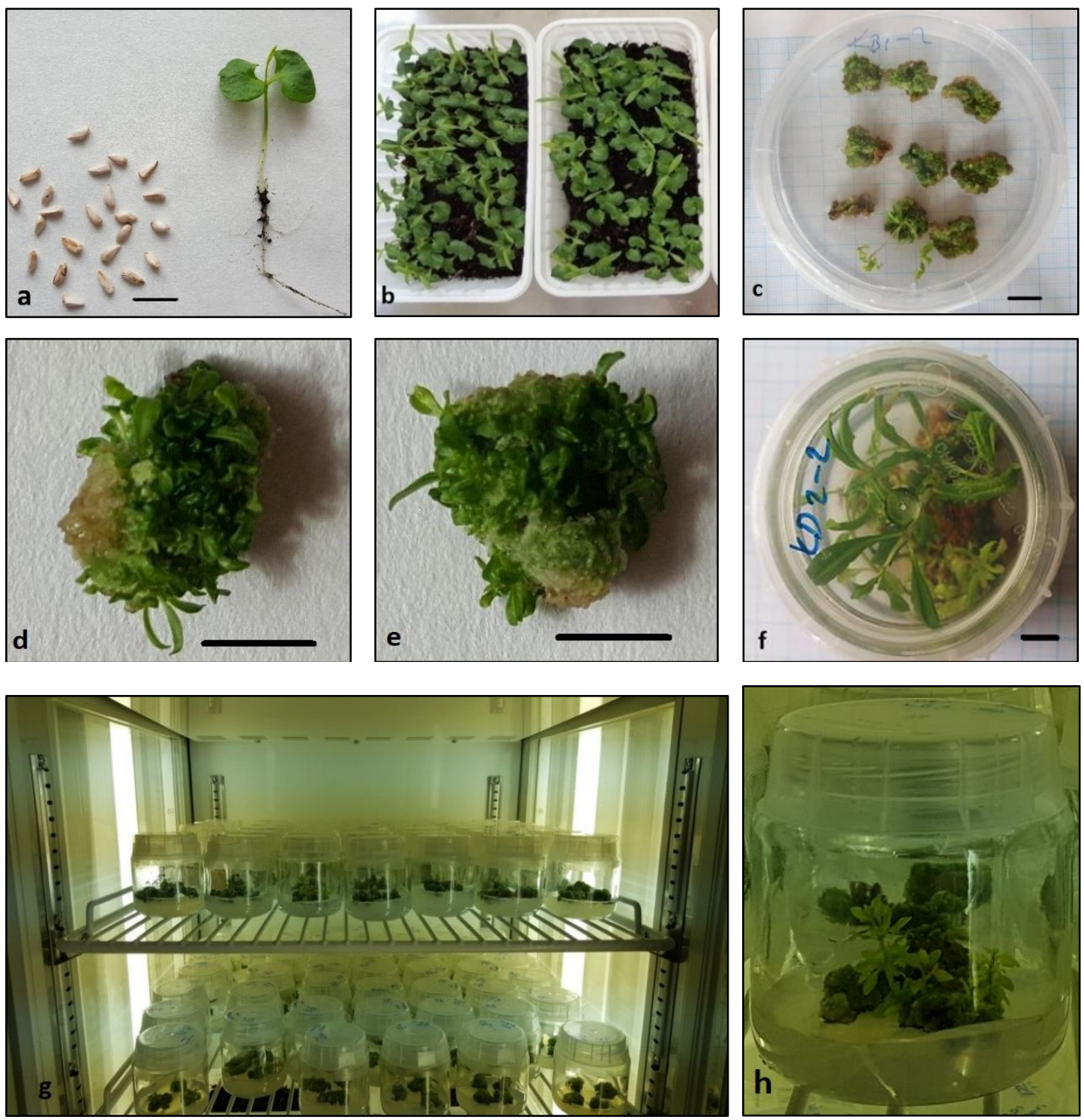

Figure 3.1. Callus induction and shoot regeneration from cotyledon explants in pomegranate (Punica granatum L. Hicaz cv.) (Original). (a) Pomegranate seeds collected from maturated pomegranate fruit and pomegranate seedling; (b) Seeds planted in plastic seedling pots containing peat for cotyledons; (c) Example of callus size observed in fully solid MS medium without activated charcoal (1.5 mg L $\left.{ }^{-1} \mathrm{BAP}+0.5 \mathrm{mg} \mathrm{L}^{-1} \mathrm{NAA}\right)\left(\mathrm{MS}+8 \mathrm{mg} \mathrm{L}^{-1}\right.$ Agar $\left.+0 \% \mathrm{AC}\right)$; (d) and (e) Callus size and shoot regeneration after 5 weeks with $2 \mathrm{mg} \mathrm{L}^{-1} \mathrm{BAP}+1 \mathrm{mg} \mathrm{L}{ }^{-1} \mathrm{NAA}$ combination (MS $+8 \mathrm{~g} \mathrm{~L}^{-1}$ Agar $+0 \% \mathrm{AC}$ ); (f) and (h) Plantlets on calli in culture jar; (g) Image of culture jars at the stage of shooth regeneration in the plant growth cabinet. (The scale bars represent $1 \mathrm{~cm}$ )

\section{Conclusions}

In our study, shoot regeneration occurred through indirect organogenesis. Therefore, callus criteria were taken into account in the evaluation of the results. Regeneration of new pomegranate shoots on these calluses was found to be practically evaluable. It is known that pomegranate fruit has rich nutritional 
content and importance in human health. Due to the increase in pomegranate consumption, the establishment of new pomegranate orchards have become important. For this reason, to obtain new clonal pomegranate plants in a short time, in vitro micropropagation using tissue culture techniques is gaining importance. The clonal micropropagation of pomegranate genotypes and varieties determined as a result of plant breeding studies will be contributed. It will also be an important source of research for gene transfer studies in pomegranate.

\section{Acknowledgement}

Our study was carried out in the laboratory of the Department of Agricultural Biotechnology, Faculty of Agriculture, Atatürk University. Moreover, this study was supported by Atatürk University Scientific Research Projects Coordination Unit (Project Number: BAP2015-391).

\section{References}

Amin M.N., Islam M.N., Azad M.A.K. (1999). Regeneration of plantlets in vitro from the seedling explants of pomegranate (Punica granatum). Plant Tissue Culture, 9:53-61.

Anonim (2018). Türkiye İstatistik Kurumu, İstatistiksel Tablolar ve Dinamik Sorgulama. [Online] Available: http://www.tuik.gov.tr/PreTablo.do?alt_id=1001(03.09.2018)

Chandra R., Babu D.K., Jadhav V.T., Teixeira da Silva, J.A. (2010). Origin, history and domestication of pomegranate. In: Chandra, R. (Ed.), Pomegranate. Fruit Vegetable and Cereal Science and Biotechnology (Special Issue) 4(2):1-6.

Deepika R., Kanwar K. (2010). In vitro regeneration of Punica granatum L. plants from different juvenile explants. Journal of Fruit and Ornamental Plant Research 18:5-22.

Foughat R.S., Pandya S.B., Ahmad T., Godhani P.R. (1997). In vitro studies in pomegranate (Punica granatum L.). Journal of Applied Horticulture Navsari 3(1/2): 23-29. [Online] Available: https://eurekamag.com/research/003/472/003472703.php(11.08.2018)

Gamborg O.L., Miller R.A., Ojima K.I. (1968). Nutrient requirements of suspension cultures of soybean root cells. Experimental Cell Research 50:151-158.

Harlan J.R. (1992). Crops and Man, 2nd Edn. American Society of Agronomy and Crop Science Society of America, Madison, WI, pp. 295.

Jaidka K., Mehra P.N. (1986). Morphogenesis in Punica granatum (Pomegranate). Canadian Journal of Botany 64:1644-1653.

Kalalbandi B.M., Waskar D.P., Khandare V.S., Gorad D.S. (2014). Micropropagation studies on pomegranate var. Bhagwa. Indian Journal of Horticulture, 71(4):564-566.

Kantharajah A.S., Dewitz I., Jabbari S. (1998). Auswirkungen unterschiedlicher Nahrmedien, Wachstums-regulatoren und Explantat quellen auf die in vitro-Vermehrung von Granatapfel (Punica granatum L.) [The effect of medium, plant growth regulators and source of explants on in vitro culture of pomegranate (Punica granatum L.). Erwerbs Obstbau, 40:54-58 (in German).

Kanwar K., Joseph J., Deepika R. (2010). Comparison of in vitro regeneration pathways in Punica granatum L.. Plant cell Tissue Organ Culture, 100:199-207.

Lloyd G.B., McCown B.H. (1980). Commercially feasible micropropagation of mountain laurel, Klamia latifolia by use of shoot tip culture. Proc. Plant Propag. Soc., 30:421-427.

Murashige T., Skoog F. (1962). A revised medium for rapid growth and bioassays with tobacco tissue culture. Physiologia Plantarum 15:473-497. 
Murkute A.A., Patil S., Patil B.N., Mayakumari, M.S. (2002). Micropropagation in pomegranate, callus induction and differentiation. South Indian Horticulture 50:49-55.

Naik S.K., Chand P.K. (2003). Silver nitrate and aminoethoxyvinylglycine promote in vitro adventitious shoot regeneration of pomegranate (Punica granatum L.). Journal of Plant Physiology, 160:423-430.

Naik, S.K., Chand P.K. (2011). Tissue culture-mediated biotechnological intervention in pomegranate: aReview. Plant Cell Reports 30:707-721.

Omura M., Matsuta T., Moriguchi T., Kozaki I. (1987a). Adventitious shoot and plantlet formation from cultured pomegranate leaf explants. Horticultural Science 22:133-134.

Omura M., Matsuta T., Moriguchi T., Kozaki I., Sanada T. (1987b). Establishment of tissue culture methods in dwarf pomegranate (Punica granatum L. var. nana) and application for induction of variants. Bulletin of the Fruit Tree Research Station 14:17-44.

Parmar N., Kanwar K., Thakur A.K. (2013). Direct Organogenesis in Punica granatum L. cv. Kandhari Kabuli from Hypocotyl Explants. Proceedings of The National Academy of Sciences India Section B-Biological Sciences 83(4):569-574.

Patil V.M., Dhande G.A., Thigale D.M., Rajput J.C. (2011). Micropropagation of pomegranate (Punica granatum L.) "Bhagava" cultivar from nodal explant. African Journal of Biotechnology, 10(79):18130-18136.

Silva J.A.T., Rana T.S., Narzary D., Verma N., Meshram D.T., Ranade S.A. (2013). Pomegranate biology and biotechnology: A review. Scientia Horticulturae 160:85-107.

Sriskandarajah S., Goodwin P.B., Speirs J. (1994). Genetic transformation of the apple scion cultivar 'Delicious' via Agrobacterium tumefaciens. Plant Cell, Tissue and Organ Culture 36(3):317-329. [Online] Available: https://link.springer.com/article/10.1007/BF00046089(11.08.2018)

Temiz M.G. (2009). Nar (Punica granatum)'da Farklı Büyüme Düzenleyicilerinin ve Farklı Eksplant Kaynaklarının Somatik Embriyogenesis Üzerine Etkileri. Çukurova Üniversitesi Fen Bilimleri Enstitüsü, Yüksek Lisans Tezi (in Turkish).

Zohary D., Spiegel-Roy P. (1975). Beginnings of fruit growing in the old world. Science 187:319. 